\title{
HUBUNGAN ANTARA RELIGIUSITAS DENGAN REGULASI DIRI PADA SANTRI MADRASAH DINIYAH DI SIDOARJO
}

\author{
Zahrotin Prasetyana $^{1,}$ Lely Ika Mariyati ${ }^{2}$ \\ Fakultas Psikologi dan Ilmu Pendidikan Universitas Muhammadiyah Sidoarjo \\ zprasetya15@gmail.com
}

\begin{abstract}
This research is motivated by the phenomenon of santri who expeinece self regulation problems. The purpose of this research to know the positive relationship between religiosity and self regulation santri madrasah diniyah at Sidoarjo. The variables in this study are religiosity as the independent variable and self regulation as the dependent variable. This research was conducted at madrasah diniyah with a total sample of 65 santri employees taken using the saturation sampling technique. Data collection techniques in this study used two Likert model psychological scales, that is the religiosity scale and self regulation scale. The hypothesis in this study is that there is a positive relationship between religiosity and self regulation santri madrasah diniyah at Sidoarjo. Data analysis was performed using product moment correlation statistics techniques of Pearson with the help SPSS for windows. The results of the analysis data of this research showed a correlation coefficient of 0.720 with a significance of $0.000<0.05$ meaning that there was a significant positive relationship and direction so that the higher the religiosity, higher the self-regulation of santri Madrasah Diniyah at Sidoarjo, and vice versa. The effective contribution of religiosity to self regulation is $51.1 \%$.
\end{abstract}

Keywords: Religiosity, Self Regulation, Santri

\begin{abstract}
ABSTRAK
Penelitian ini dilatar belakangi oleh adanya fenomena santri yang mengalami permasalahan regulasi diri. Penelitian ini bertujuan untuk mengetahui hubungan positif antara religiusitas dan regulasi diri pada santri madrasah diniyah di Sidoarjo. Variabel yang terdapat dalam penelitian ini adalah religiusitas sebagai variabel bebas dan regulasi diri sebagai variabel terikat. Penelitian ini dilakukan di madrasah diniyah dengan jumlah sampel sebanyak 65 santri yang diambil dengan menggunakan teknik sampling jenuh. Teknik pengumpulan data dalam penelitian ini menggunakan dua skala psikologi model Likert, yaitu skala religiusitas dan skala regulasi diri. Hipotesis dalam penelitian ini adalah adanya hubungan positif antara religiusitas dengan regulasi diri pada santri madrasah diniyah di Sidoarjo. Analisis data dilakukan dengan teknik statistik korelasi product moment dari Pearson menggunakan bantuan program SPSS for windows. Hasil analisis data penelitian ini menunjukkan koefisien korelasi sebesar 0,720 dengan signifikansi $0,000<0,05$ artinya ada hubungan positif antara religiusitas dengan regulasi diri yang signifikan dan searah. Sehingga semakin tinggi religiusitas maka semakin tinggi pula regulasi diri pada santri di Madrasah Diniyah di Sidoarjo, begitu pula sebaliknya. Adapun sumbangan efektif religiusitas terhadap regulasi diri adalah sebesar 51,1\%.
\end{abstract}

Kata Kunci: Religiusitas, Regulasi Diri, Santri 


\section{PENDAHULUAN}

Salah satu lembaga pendidikan yang lebih tinggi memprioritaskan upaya meningkatkan kecerdasan spiritual atau keagamaan ialah pesantren. Pesantren adalah rumah umum atau tempat publik untuk para santri belajar ilmu agama. Salah satu bagian dari pendidikan agama formal di pesantren adalah Madrasah Diniyah yang merupakan suatu lembaga pendidikan keagamaan yang secara terus menerus memberikan pendidikan agama islam kepada para santri yangmana pendidikan tersebut tidak terpenuhi pada jalur sekolah. Sistem pengajaran yang diterapkan di madrasah diniyah yaitu melalui sistem klasikal dengan jenjang pendidikan yang telah ditentukan (Depag, 2000). Madrasah Diniyah merupakan madrasah yang seluruh mata pelajaranya bermaterikan ilmu-ilmu agama, yaitu fiqih, tafsir, tauhid dan ilmu-ilmu agama lainya (Haedar \& El-Saha 2008).

Santri yang menempuh pendidikan di madrasah diniyah berusia antara 13-19 tahun yang bertepatan berasa pada masa remaja. Sebagaimana teori psikososial Erickson yang menyatakan bahwa masa remaja menuju dewasa merupakan masa pencarian jati diri yang mencakup perubahan biologis, kognitif, dan sosial-emosional (Santrock, 2012). Sehingga perlu adanya regulasi diri yang baik pada remaja.

Berdasarkan hasil wawancara yang penulis lakukan dengan salah seorang ustadz madrasah diniyah di Sidoarjo tersebut menyatakan bahwa :

"Iya, memang ada santri yang apabila ditegur oleh ustadz gitu, dia tidak bantah hanya nunduk ajah, tapi besoknya dia tidak masuk ngaji. Terus ada juga yang kalo diingatkan temannya gitu, eh malah jadi ribut."

Selain itu penulis juga mewawancarai santri madrasah diniyah di Sidoarjo. Berdasarkan wawancara tersebut penulis menemukan fenomena adanya santri yang kurang mampu mengobservasi diri dengan baik sehingga seringkali menunjukkan reaksi diri yang kurang baik. Misalnya ketika santri tersebut ditegur karena melakukan kesalahan santri tersebut merespon 
dengan marah. Sehingga dapat dikatakan bahwa ada santri yang kurang mampu dalam melakukan regulasi diri.

Regulasi diri merujuk pada pikiran, perasaan, dan tindakan yang terencana oleh diri dan terjadi secara berkesinambungan sesuai dengan upaya pencapaian tujuan (Zimmerman, 2000). Carver \& Scheier juga menyatakan bahwa regulasi diri merupakan konseptualisasi dari kemampuan mengontrol dan mengarahkan tindakan atau perilakunya dalam mencapai tujuan (Diamond \& Aspinwall, 2003).

Menurut Bandura regulasi diri adalah kemampuan seseorang untuk mengontrol perilakunya sendiri dan mempertahankan komitmennya terhadap suatu tujuan selama periode waktu tertentu (Ormrod, 2012). Aspek-aspek regulasi diri menurut Bandura, Schunk dan Zimmerman terdiri dari 5 aspek yaitu 1) mengatur standar dan tujuan (setting standards and goals), kemampuan individu dalam menetapkan standar perilaku untuk diri sendiri, 2) observasi diri (self-observation), individu mampu mengetahui kelebihan dan kekurangan pada diri sendiri, 3) evaluasi diri (self-evaluation), individu mampu menilai diri sendiri sesuai dengan standar yang telah ditetapkan, 4) reaksi diri (self reaction), yaitu respon yang diberikan terhadap perilaku diri sendiri, dan 5) refleksi diri (self-reflection), individu mampu merenungkan secara rinci perilaku serta tujuan yang telah ditetapkannya (Santoso, 2015).

Menurut Bandura terdapat 2 faktor yang mempengaruhi regulasi diri yaitu faktor eksternal dan internal. Faktor eksternal merupakan faktor yang berkaitan dengan lingkungan sekitar individu yang akan mempengaruhi pengetahuan individu dan motivasi diri. Sedangkan faktor internal merupakan faktor yang merujuk pada kognitif individu dalam mengatur dan mengontrol perilakunya berdasarkan standar pribadi maupun performa rujukan yang telah disesuaikan dengan tujuan yang dibuatnya (Alwisol, 2016). Selain faktor-faktor tersebut, 
Mccullough \& Willoughby (2009) menyatakan bahwa regulasi diri secara efektif dipengaruhi oleh religiusitas seseorang sejauhmana keyakinan seseorang tersebut terhadap agamanya.

Menurut Glock \& Stark religiusitas merupakan tingkat konsepsi dan komitmen seseorang terhadap agamanya yang meliputi dimensi-dimensi yang berpusat pada Tuhan (Ula, 2018). Dimensi religiusitas menurut Glock \& Strack terdapat 5 dimensi yaitu, 1) Keyakinan individu terhadap agamanya, b) peribadatan, ritual sakral yang harus dilaksanakan sesuai tuntunan agama, c) pengalaman, cara seseorang mengekspresikan keyakinan agamannya, d) pengetahuan seseorang tentang ajaran-ajaran agamanya, dan e) penghayatan seseorang sejauhmana keyakinannya terhadap agama yang dianutnya (Laiyina, 2016).

Pada penelitian sebelumnya yang dilakukan oleh Nabila \& Laksmiwati (2019) menemukan fenomena adanya santri yang seringkali bertindak semaunya dan mengabaikan peraturan yang ada di pesantren dan kurang mampu mengatur waktu dengan baik. Sedangkan menurut penelitian lainnya yang dilakukan oleh Husna, dkk (2018) dengan salah satu santriwati di SMP Darul Hijrah Putri, menyatakan bahwa jika ada dalam masalah ia menerima kegagalan dengan cara bertawakal kemudian juga berusaha bangkit lagi dan merencanakan tujuan. Hal tersebut pada regulasi diri berkaitan dengan aspek refleksi diri dan reaksi diri yaitu kemampuan seseorang dalam mengukur keberhasilan maupun kegagalan yang dialaminya berdasarkan kemampuan diri. Kemudian seseorang tersebut mampu memberikan penguatan pada keberhasilan maupun kegagalan diri.

Hal ini selaras dengan penelitian yang dilakukan oleh Melsani (2018) yang menyatakan bahwa dengan meningkatkan religiusitas seseorang akan lebih mampu membentuk pribadi yang baik, karena ajaran-ajaran agama mampu menjadi pedoman atau pegangan bagi diri seseorang. Sehingga dengan religous reference (sumber pegangan keagaaman) seseorang akan memiliki konsep diri yang baik dan mampu mengendalikan perbuatan baik atau buruk . 
Santri yang memiliki religiusitas yang tinggi sebagaimana santri mendapat pengetahuan dan pemahan akan ilmu agama serta meyakini ajaran agama serta mengamalkannya maka santri tersebut akan lebih mampu untuk menentukan standar perilaku dan tujuan hidup, mengobservasi diri, reaksi diri dan refleksi diri yang baik. Sehingga santri akan memiliki regulasi diri yang tinggi. Sedangkan santri yang memiliki religiusitas yang rendah sebagaimana santri kurang dalam pengetahuan dan pemahan ilmu agama, serta kurangnya keyakinan terhadap ajaran agama maka santri tersebut akan kurang mampu untuk menentukan standar perilaku dan tujuan hidup, mengobservasi diri, reaksi diri dan refleksi diri. Sehingga santri tersebut memiliki regulasi diri yang rendah.

Tujuan dari penelitian ini adalah untuk mengetahui adakah hubungan antara religiusitas dengan regulasi diri pada santri madrasah diniyah di Sidoarjo. Manfaat secara teoritis dalam penelitian ini diharapkan dapat menjadi bahan kajian lebih lanjut dalam hal pengembangan di bidang psikologi, khususnya psikologi kepribadian dan pendidikan. Manfaat praktis : Bagi santri dapat memberikan informasi tentang pentingnya religiusitas dengan regulasi diri agar dapat mencapai tujuan dengan optimal. Bagi madrasah diniyah dapat memberikan informasi kepada Madrasah Diniyah untuk digunakan sebagai tolak ukur para santri dalam hal religiusitas dengan regulasi diri. Bagi peneliti dapat menjadi bahan acuan pada penelitian selanjutnya di masa yang akan mendatang, khususnya pada bidang pendidikan di Madrasah Diniyah.

\section{METODE PENELITIAN}

Penelitian ini merupakan penelitian yang menggunakan metode penelitian kuantitatif korelasional. Tujuan menggunakan metode ini yaitu untuk mengetahui hubungan antar variabel. pada penelitian ini terdapat 2 variabel, yaitu "Religiusitas" sebagai variabel 
independent atau variabel bebas dan "Regulasi diri" sebagai variabel dependent atau variabel terikat.

Subjek penelitian ini merupakan santri madrasah diniyah berjumlah 65 santri. Teknik pengambilan sampel menggunakan teknik sampling jenuh sehingga keseluruhan jumlah populasi digunakan sebagai sampel yaitu sebanyak 65 santri.

Teknik pengumpulan data menggunakan 2 skala yaitu skala, yaitu a) skala religiusitas berdasarkan dimensi-dimensi religiusitas Glock \& Strack dengan nilai validitas yang bergerak dari 0,253 sampai dengan 0,647 dan nila reliabilitas 0,841, b) skala regulasi diri berdasarkan aspek-aspek regulasi diri menurut Bandura, Schunk dan Zimmerman dengan nilai validitas yang bergerak dari 0,310 sampai dengan 0,794 dan nilai reliabilitas 0,945 . Selain menggunakan validitas isi ini juga menggunakan pertimbangan dari professional judgment untuk menentukan kesesuaian aitem-aitem yang ada dengan kaidah penyusunan skala. Analisis data untuk uji asumsi prasyarat yaitu menggunakan uji normalitas dan linearitas sedangkan analisis data untuk uji hipotesis menggunakan korelasi product moment pearson dengan bantuan program SPSS 18 for windows.

\section{HASIL PENELITIAN}

Sebelum melakukan uji hipotesis di lakukan uji prasyarat diantaranya yaitu : a) Uji normalitas bertujuan untuk melihat apakah data bertribusi normal atau tidak. Hasil analisis di dapatkan bahwa religiusitas memiliki distribusi normal dengan nilai 0,336 >0,05. Analisis uji normalitas data regulasi diri berdistribusi normal dengan nilai 0,449 $>0,05$ Sehingga dapat dikatakan bahwa semua data berdistribusi normal. b) Uji linearitas digunakan untuk mengatahui kedua variabel memiliki hubungan linear atau tidak. Analisis data religiusitas memiliki pola data linear karena nilai deviation from linearity sebesar 0,072>0,05. c) analisis 
deskriptif data hasil penelitian yakni model kategorisasi yang peneliti gunakan untuk mengelompokkan individu pada suatu posisi atau jenjang menurut kontinum berdasarkan atribut yang diukur (Azwar, 2015). Kontinum jenjang pada penelitian ini menggunakan lima jenjang yakni dari jenjang sangat rendah ke sangat tinggi.

Tabel 1. Kategorisasi Subjek

\begin{tabular}{ccccc}
\hline \multirow{2}{*}{ Kategori } & \multicolumn{3}{c}{ Jumlah Subjek Pada Masing-Masing } \\
Skala \\
\cline { 2 - 5 } & \multicolumn{2}{c}{ Religiusitas } & \multicolumn{2}{c}{ Regulasi Diri } \\
\cline { 2 - 5 } & $\begin{array}{c}\sum \text { Subjek } \\
\text { Subjek }\end{array}$ & \% \\
\hline Sangat Rendah & 0 & 0.00 & 0 & 0.00 \\
Rendah & 0 & 0.00 & 0 & 0.00 \\
Sedang & 0 & 0.00 & 1 & 1.5 \\
Tinggi & 6 & 9.2 & 30 & 46.2 \\
Sangat Tinggi & 59 & 90.8 & 34 & 52.3 \\
TOTAL & $\mathbf{6 5}$ & $\mathbf{1 0 0 . 0 0}$ & $\mathbf{6 5}$ & $\mathbf{1 0 0 . 0 0}$
\end{tabular}

Berdasarkan tabel ketegorisasi skor subyek diatas maka dapat disimpulkan bahwa santri madrasah diniyah di Sidoarjo yang berjumlah 65 santri memiliki religiusitas yang sangat tinggi sebanyak 90,8\%, dan santri dengan religiusitas tinggi sebanyak 9,2\%. Begitu pula dengan regulasi diri yakni santri yang memiliki regulasi diri yang sangat tinggi sebanyak 52,3\%, santri dengan regulasi diri tinggi sebanyak 46,2\%, dan santri dengan regulasi diri sedang sebanyak $1,5 \%$.

Setelah uji prasyarat di penuhi maka peneliti melakukan uji hipotesis yaitu ada hubungan antara religiusitas dengan regulasi diri pada santri madrasah diniyah di Sidoarjo. Hasil penelitian dapat di lihat pada tabel 2 analisis korelasi product momen pearson. 
Tabel 2. Analisis Korelasi Product Moment Pearson

\begin{tabular}{llrr}
\hline & & Religiusitas & Regulasi_Diri \\
\hline Religiusitas & Pearson Correlation & 1 & $.720^{* *}$ \\
& Sig. (1-tailed) & & .000 \\
& N & 65 & 65 \\
\multirow{2}{*}{ Regulasi_Diri } & Pearson Correlation & $.720^{* *}$ & 1 \\
& Sig. (1-tailed) & .000 & 65 \\
& N & 65 & \\
\end{tabular}

Berdasarkan hasil uji hipotesis pada tabel 2 diperoleh nilai signifikansi $0,000<0,05$ dengan nilai rxy sebesar 0,720 . Sehingga hipotesis diterima yang artinya ada hubungan antara religiusitas dengan regulasi diri pada santri madrasah diniyah di Sidoarjo.

Setelah melakukan uji hipotesis selanjutnya peneliti menghitung hasil koefisien determinasi. Hasil koefisien determinasi dapat dilihat di tabel berikut :

Tabel 3. Hasil Koefisien Determinasi

\begin{tabular}{|c|c|c|c|c|}
\hline \multicolumn{5}{|c|}{ Model Summary } \\
\hline Model & $\mathrm{R}$ & R Square & $\begin{array}{l}\text { Adjusted R } \\
\text { Square }\end{array}$ & $\begin{array}{l}\text { Std. Error of the } \\
\text { Estimate }\end{array}$ \\
\hline 1 & $.720^{\mathrm{a}}$ & .518 & .511 & 3.617 \\
\hline a. Pred & (Consta & t), Religiusit & & \\
\hline
\end{tabular}

Berdasarkan hasil uji koefisien determinasi pada tabel 3 menunjukkan 0,511 (Adjusted $R$ Square) bahwa dalam penelitian ini besarnya kontribusi religiusitas terhadap variabel regulasi diri sebesar $51,1 \%$.

\section{DISKUSI}

Berdasarkan uraian di atas dapat diketahui bahwa ada hubungan positif antara religiusitas dengan regulasi diri pada santri madrasah diniyah di Sidoarjo. Artinya, semakin tinggi religiusitas santri maka akan semakin tinggi regulasi diri santri. Sebaliknya pula, semakin rendah religiusitas santri maka akan semakin rendah regulasi diri santri. 
Hasil penelitian ini sejalan dengan penelitian sebelumnya yang dilakukan oleh Koole, el, al (2017) menyatakan bahwa ritual keagamaan secara adaptif membentuk pola perilaku seseorang sesuai dengan ketaatan individu dalam meyakini agamanya. Selain itu, sebagaimana penelitian yang dilakukan oleh Melsani (2018) menyatakan bahwa dengan meningkatkan religiusitas seseorang akan lebih mampu membentuk pribadi yang baik, karena ajaran-ajaran agama mampu menjadi pedoman atau pegangan bagi diri seseorang. Sehingga dengan religous reference (sumber pegangan keagaaman) seseorang akan memiliki konsep diri yang baik dan mampu mengendalikan perbuatan baik atau buruk .

Pada penelitian ini juga diperoleh hasil kategorisasi subjek. Dari uraian di atas dapat diketahui bahwa santri yang memiliki regulasi diri yang sangat tinggi sebanyak 34 santri $(52,3 \%)$, sebanyak 30 santri $(46,2 \%)$ memiliki regulasi diri yang tinggi, sebanyak 1 santri $(1,5 \%)$ memiliki regulasi diri sedang, dan tidak ada santri yang memiliki religiusitas rendah, maupun sangat rendah. Hal ini menunjukkan bahwa sebagian besar santri madrasah diniyah di Sidoarjo memiliki regulasi diri yang sangat tinggi dengan indikasi cerminan perilaku santri. Kemampuan santri dalam mengatur standar dan tujuan yang akan dicapainya dengan mempertimbangan kemampuan diri dan norma yang berlaku di lingkungannya. Sehingga santri akan lebih mampu memberikan reaksi diri positif dalam menyikapi suatu permasalahan.

Hasil kategorisasi penelitian ini juga menunjukkan jumlah santri yang memiliki religiusitas sangat tinggi sebanyak 59 santri (90,8\%), sebanyak 6 santri (9,2\%) memiliki religiusitas tinggi, dan tidak ada santri yang memiliki religiusitas sedang, rendah, maupun sangat rendah. Hal ini menunjukkan bahwa sebagian besar santri madrasah diniyah di Sidoarjo memiliki religiusitas yang sangat tinggi dengan indikasi keyakinan santri terhadap agamanya dan menjadikan ajaran agamanya sebagai pengetahun dan pedoman hidup. Hal ini kemudian akan tercermin pada perilaku santri dalam menerapkan ajaran agamanya, dengan melaksanakan 
peribadatan keagamaan, memiliki kepedulian dan bersedia membantu terhadap sesama, serta senantiasa berusaha menjadi pribadi yang baik karena adanya keyakinan bahwa setiap perbuatan pasti ada konsekuensinya baik maupun buruk.

\section{KESIMPULAN DAN SARAN}

Simpulan dari penelitian ini dapat ditarik dari hasil dan pembahasan penelitian di atas, yaitu terdapat hubungan positif antara religiusitas dengan regulasi diri pada santri madrasah diniyah di Sidoarjo. Hal ini dibuktikan dengan hasil analisis yang menunjukkan koefisien relasi yang kuat, yakni rxy sebesar 0,720 dengan signifikansi (p) sebesar 0,000 (lebih kecil dari 0,05). Dengan demikian berarti semakin tinggi religiusitas santri maka semakin tinggi pula regulasi diri santri. Begitu pula sebaliknya, semakin rendah religiusitas santri maka semakin rendah pula regulasi diri santri. Sumbangan efektif variabel $\mathrm{X}$ (religiusitas) terhadap variabel $\mathrm{Y}$ (regulasi diri) adalah sebesar 51,1\%.

Saran yang dapat dikemukakan sebagaimana berikut: a) bagi santri : santri diharapkan mampu mempertahankan konsistensi kemampuan regulasi diri demi pencapaian tujuan dan nantinya akan berguna dalam tahap perkembangan selanjutnya, b) bagi madrasah : madrasah diharapkan mampu menambah pembelajaran maupun kajian-kajian islami untuk memperdalam dan menambah wawasan keislaman pada santri, c) bagi peneliti selanjutnya : peneliti selanjutnya diharapkan dapat mengembangkan penelitian terkait regulasi diri dengan menggunakan metode penelitian yang lain serta dengan subyek yang lebih banyak.

\section{DAFTAR PUSTAKA}

Alwisol. (2016). Psikologi Kepribadian (Edisi Revisi). Malang: UMM Press Azwar, S. (2015). Penyusunan Skala Psikologi Edisi Revisi. Yogyakarta: Pustaka Pelajar. 
Departemen Agama RI. (2000). Pedoman penyelenggaraan dan Pembinaan Madrasah Diniyah. Jakarta: Depag

Diamond, Lisa M, \& Aspinwall, Lisa G. (2003). Emotion Regulation Across the Life Span: An Integrative Perspective Emphasizing Self-Regulation, Positive Affect, and Dyadic Processes. Journal of Motivation and Emotion. Vol. 27, No.2.

Haedar, A. \& El-Saha, M. I. (2008). Peningkatan Mutu Terpadu Pesantren dan Madrasah Diniyah. Jakarta: Diva pustaka.

Husna, T. A., Mayangsari, M. D., \& Rachmah, D. N. (2018). Peranan Kecerdasan Spiritual terhadap Regulasi Diri dalam Belajar pada Santriwati di SMP Darul Hijrah Puteri Martapur. Jurnal Ecopsy, Vol 5, No 1.

Koole, S. L., Meijer, M., \& Remmers, C. (2017). Religious rituals as tools for adaptive selfregulation. Religion, Brain \& Behavior, 7:3, 250-253.

Laiyina, S. Z. (2016). Hubungan religiuistas dan kontrol diri dengan kepatuhan santri pada aturan di Pondok Pesantren Sabilurrosyad Karangbesuki Sukun Malang. Skripsi diterbitkan, Universitas Islam Negeri Maulana Malik Ibrahim Malang.

McCullough, M. E. \& Willoughby, B. L. B. (2009). Religion, self-regulation, and self-control: Associations, explanations, and implications. Psychological Bulletin, 09, 29-33.

Melsani. 2018. Bimbingan agama dalam meningkatkan regulasi diri narapidana di Rumah Tahanan (Rutan) Kelas II B Menggala Tulang Bawang. Skripsi diterbitkan, Universitas Islam Negeri Raden Intan.

Nabila, N. \& Laksmiwati, H. (2019). Hubungan antara regulasi diri dengan penyesuaian diri pada santri remaja Pondok Pesantren Darut Taqwa Ponorogo. Jurnal Penelitian Psikologi, Vol 06, No 03.

Ormrod, J. E. (2012). Human Learning. 6th. ed. New York: Pearson.

Santoso, S. L. (2015). Hubungan regulasi diri dengan coping stress berfokus masalah pada pengurus ORMAWA FIP UNY. Skripsi diterbitkan, Universitas Negeri Yogyakarta.

Santrock. (2012). Life-span Development (Perkembangan Masa Hidup) Jilid 1. Jakarta: Penerbit Erlangga. alih bahasa: Benedictine Wisdyasinta.

Ula, Z. (2018). Hubungan antara religiuisitas dengan kecenderungan perilaku delinquency remaja pada siswa SMP Hasan Munadi Beji Pasuruan. Skripsi diterbitkan, Universitas Muhammadiyah Sidoarjo.

Zimmerman, B. J. (2000). Attaining self-regulation: A social cognitive perspective. In Handbook of Self-Regulation. San Diego Academic Press. 
PSYCHE: JURNAL PSIKOLOGI UNIVERSITAS MUHAMMADIYAH LAMPUNG

ISSN (electronic) 2655-6936 ISSN (printed) 2686-0430 